\title{
AKTIVITAS ANTIOKSIDAN Caulerpa sp. SEGAR DAN REBUS
}

\section{Taufik Hidayat ${ }^{1 \star}$, Nurjanah $^{2}$, Agoes Mardiono Jacoeb ${ }^{2}$, Bagja Adhitia Putera ${ }^{2}$}

\author{
${ }^{1}$ Pusat Teknologi Agroindustri, Badan Pengkajian dan Penerapan Teknologi, Gedung Laptiab 610 \\ Puspiptek Serpong \\ ${ }_{2}^{2}$ Departemen Teknologi Hasil Perairan, FPIK IPB University, Jalan Agatis, Kampus IPB Dramaga, \\ Kabupaten Bogor 16680 Jawa Barat Telepon (0251) 8622915, faks (0251) 8622916 \\ Diterima: 28 Agustus 2020/Disetujui: 28 Desember 2020 \\ *Korespondensi: besthd22@gmail.com
}

Cara sitasi: Hidayat T, Nurjanah, Jacoeb AM, Putera BA. Aktivitas antioksidan Caulerpa sp. segar dan rebus. Jurnal Pengolahan Hasil Perikanan Indonesia. 23(3): 566-575.

\begin{abstract}
Abstrak
Radikal bebas merupakan suatu molekul yang sangat reaktif dan tidak stabil, dapat mengakibatkan kerusakan protein, Deoxyribonucleic Acid (DNA), dan membran sel, serta dapat memicu timbulnya penyakit degeneratif. Kerusakan-kerusakan tersebut dapat dicegah dengan senyawa antioksidan alami maupun sintetik. Caulerpa sp. merupakan rumput laut hijau yang berpotensi sebagai sumber antioksidan alami. Caulerpa sp. umum diolah menjadi urap rumput laut dalam keadaan segar dan rebus. Proses perebusan dikhawatirkan dapat mengubah aktivitas antioksidannya, sehingga perlu dilakukan penelitian mengenai aktivitas antioksidan pada Caulerpa sp. segar dan rebus. Penelitian ini bertujuan menentukan suhu dan waktu perebusan terpilih, komposisi kimia, dan aktivitas antioksidan di dalam rumput laut Caulerpa sp. segar dan setelah proses perebusan.Metode ekstraksi yang digunakan adalah ekstraksi tunggal menggunakan pelarut metanol selama $1 \times 24$ jam. Pengujian aktivitas antioksidan dilakukan menggunakan metode DPPH. Caulerpa sp. segar dan rebus memiliki rendemen ekstrak yaitu 8,88\% dan 6,44\%. Nilai IC $_{50}$ Caulerpa sp.

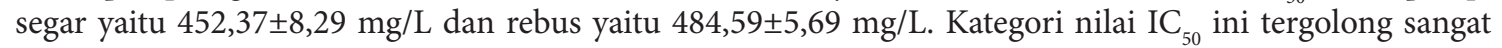
lemah berdasarkan metode 1,1-diphenyl-2-picrylhydrazyl (DPPH), sehingga perlu dilakukan uji aktivitas antioksidan dengan metode lainnya dan pemurnian ekstrak kasar Caulerpa sp.
\end{abstract}

Kata kunci: DPPH, ekstraksi, latoh, radikal bebas

\section{Antioxidant Activity of Fresh and Boiled Caulerpa sp.}

\begin{abstract}
Free radical is a molecule that is highly reactive and unstable, can cause damage to proteins, Free radical is a molecule that is highly reactive and unstable, can cause damage to proteins, Deoxyribonucleic Acid (DNA), and cell membranes, and can trigger a degenerative diseases. The damages can be prevented by natural or synthetic antioxidant compounds. Caulerpa sp. a green seaweed as a potential source of natural antioxidants. Caulerpa sp. commonly processed into "urap" seaweed in fresh and boiled condition. The boiling process may change the antioxidant activity, so it is necessary to research on the antioxidant activity in Caulerpa sp. fresh and boiled. Extraction method used was a single extraction using methanol p.a for $1 \times 24$ hours. Testing of antioxidant activity using DPPH method. Caulerpa sp. fresh and boiled extract has a yield of $8.88 \%$ and $6.44 \%$. $\mathrm{IC}_{50}$ values Caulerpa sp. fresh amounted to $452.37 \pm 8.29 \mathrm{mg} / \mathrm{L}$ and boiled amounted to $484.59 \pm 5.69 \mathrm{mg} / \mathrm{L}$. IC50 value category is classified as very weak by 1,1-diphenyl-2-picrylhydrazyl (DPPH) method, so it needs to do another antioxidant activity assay methods and purification of crude extract of Caulerpa sp.
\end{abstract}

Keyword: DPPH, extraction, free radical, latoh 


\section{PENDAHULUAN}

Radikal bebas merupakan molekul yang sangat reaktif dan tidak stabil karena memiliki satu atau lebih elektron yang tidak berpasangan. Molekul ini merupakan hasil samping dari proses oksidasi atau proses metabolisme organisme aerobik. Radikal bebas berperan sebagai sistem pertahanan tubuh untuk melawan virus dan bakteri yang masuk, namun jika jumlah yang dihasilkan berlebih, maka dapat mengakibatkan kerusakan protein, DNA, dan membran sel. Kerusakan-kerusakan tersebut dapat memicu timbulnya penyakit degeneratif antara lain kanker, penyakit katarak, diabetes, dan tekanan darah tinggi (Deepa et al. 2007).

Udayaprakash et al. (2015) menyatakan kerusakan-kerusakan yang dihasilkan oleh radikal bebas dapat dicegah dengan senyawa antioksidan yang dihasilkan oleh tubuh yaitu enzim katalase, superoksida dismutase (SOD), dan glutation peroksida, maupun senyawa antioksidan yang berasal dari asupan makanan. Asupan makanan dapat berupa senyawa alami yaitu vitamin A, C, E, dan fenol, serta senyawa sintetik yaitu Butylated Hydroxyanisol (BHA), Butylated Hydroxytoluene (BHT), dan Propylgallate (PG) (Jebakumar et al. 2012).

Antioksidan dikategorikan menjadi dua, yaitu sintetik dan alami. Penggunaan senyawa antioksidan sintetik sudah sangat diawasi, karena pada penggunaan dalam waktu yang lama dapat menyebabkan efek negatif terhadap kesehatan serta meningkatkan terjadinya karsinogenesis (Winarno 2008). Batas maksimum penggunaan BHT dan vitamin C pada makanan adalah $200 \mathrm{mg} / \mathrm{L}$ atau $0,02 \%$ dan $500 \mathrm{mg} / \mathrm{kg}$ (BSN 1995).

Aktivitas antioksidan dari beberapa tumbuhan air telah banyak dilaporkan, antara lain Sudirman et al. (2014) melaporkan bahwa $\mathrm{IC}_{50}$ pada buah bakau yaitu $13,46 \mathrm{mg} / \mathrm{L}$, Nurjanah et al. (2015) menyatakan bahwa $\mathrm{IC}_{50}$ pada kulit batang buah lindur yaitu $56,93 \mathrm{mg} / \mathrm{L}$. Santoso et al. (2012) menyatakan bahwa $\mathrm{IC}_{50}$ pada lamun Thalassia hermprichii yaitu 214,68 mg/L. Nurjanah et al. (2014) menyatakan bahwa $\mathrm{IC}_{50}$ pada tanaman genjer segar dan rebus selama lima menit masingmasing yaitu $131 \mathrm{mg} / \mathrm{L}$ dan 3409 mg/L.
Caulerpa sp. merupakan rumput laut hijau yang tumbuh di laut dangkal dengan aliran air yang tenang. Caulerpa sp. memiliki spektrum kimia dan biologi yang cukup luas termasuk aktivitas antioksidan dalam menangkal radikal bebas (Sultana et al. 2011). Kebiasaan masyarakat Tual, pesisir Jawa, dan Sulawesi mengonsumsi Caulerpa sp. dalam bentuk urap rumput laut segar, sedangkan masyarakat Bali mengolahnya menjadi urap melalui proses perebusan terlebih dahulu. Penelitian terkait Caulerpa sp. yang telah dilakukan yaitu penentuan total fenol (Nurjanah et al. 2019), bahan baku kosmetik (Nurjanah et al. 2016), analisis komponen serat (Nurjanah et al. 2018), dan antioksidan aktivitas Caulerpa lentillifera telah dilaporkan oleh Maulida (2007) dengan nilai IC $_{50} 356,13$ ppm (segar) dan 5090,39 ppm (kering). Nufus et al. 2017 juga meneliti Caulerpa lentillifera dengan antioksidan 47,61 $\mathrm{mg} / \mathrm{L}$. Namun, data aktivitas antioksidan Caulerpa sp. dengan proses rebus masih minim informasi. Proses perebusan yang terjadi dapat menginaktifkan enzim dan mikroba namun dikhawatirkan mengurangi aktivitas antioksidan yang ada dalam rumput laut hijau tersebut, sehingga perlu dilakukan penelitian mengenai aktivitas antioksidan pada Caulerpa sp. segar dan rebus. Penelitian ini bertujuan menentukan suhu dan waktu perebusan terpilih, komposisi kimia, dan aktivitas antioksidan di dalam rumput laut Caulerpa sp. segar dan setelah proses perebusan.

\section{BAHAN DAN METODE Bahan dan Alat}

Bahan yang digunakan adalah rumput laut hijau Caulerpa sp. yang berasal dari perairan Tual, Maluku Tenggara. Bahanbahan untuk analisis antara lain metanol p.a. (Merck), etanol p.a (Merck), n-heksana p.a (Merck), $\mathrm{H}_{2} \mathrm{SO}_{4}$ (Merck), $\mathrm{NaOH} 40 \%$ (Merck), $\mathrm{H}_{3} \mathrm{BO}_{3}$, (Merck) $\mathrm{HCl}$ (Merck), kristal DPPH (Aldrich), vitamin C (IPI). Alat-alat yang digunakan antara lain timbangan digital (Quattro), orbital shaker (WiseShake), rotary vacuum evaporator (Eyela), microplate, dan spektrofotometer Elisa Reader (Biotek). 


\section{Metode Penelitian}

Penelitian yang dilakukan dibagi menjadi dua tahap yaitu penelitian pendahuluan dan utama. Penelitian pendahuluan dilakukan menentukan suhu dan waktu perebusan. Penentuan suhu dan waktu perebusan dilakukan dengan merebus sampel Caulerpa sp. dalam suhu $90{ }^{\circ} \mathrm{C}$ dan $95{ }^{\circ} \mathrm{C}$ dengan waktu perebusan selama $1,3,5$, dan 7 menit. Penelitian utama dilakukan untuk menentukan komposisi kimia dan aktivitas antioksidan dari Caulerpa sp. segar dan rebus.

\section{Prosedur penelitian}

Sampel Caulerpasp. segar ditransportasikan dengan pesawat dari Tual Isampai Jakarta, disimpan dalam plastik dan dimasukkan ke dalam toples plastik. Sampel ditransportasikan menggunakan mobil dari Jakarta sampai Laboratorium Karakteristik Bahan Baku Hasil Perairan, kemudian sampel disimpan dalam suhu ruang tanpa tertutup dan terhindar dari air tawar. Caulerpa sp. segar berdasarkan pengalaman empiris memiliki daya awet selama satu minggu jika dibiarkan dalam suhu ruang tanpa tertutup dan tidak terkena air tawar. Pengamatan morfologi sampel dilakukan untuk menentukan ciri-ciri sampel Caulerpa sp.

\section{Preparasi dan perebusan Caulerpa sp.}

Caulerpa sp. dibersihkan dari kotoran yang masih menempel, kemudian dilakukan penimbangan untuk mengetahui bobot awal sampel. Air sebanyak $800 \mathrm{~mL}$ dituang ke gelas piala $1 \mathrm{~L}$ kemudian dipanaskan menggunakan kompor listrik. Sampel sebanyak $200 \mathrm{~g}$ dimasukkan ke dalam gelas piala tersebut setelah suhu perebusan mencapai suhu $90{ }^{\circ} \mathrm{C}$ dan $95^{\circ} \mathrm{C}$. Proses perebusan dilakukan selama 1, 3, 5, dan 7 menit, kemudian diuji organoleptik untuk menetapkan suhu dan waktu perebusan terpilih.

\section{Uji Organoleptik (Setyaningsih et al. 2010)}

Pengujian organoleptik secara hedonik lebih spesifik untuk menentukan tingkat kesukaan panelis terhadap parameter kenampakan, warna, aroma, rasa, dan tekstur.
Caulerpa sp. direbus dengan suhu $90{ }^{\circ} \mathrm{C}$ dan $95^{\circ} \mathrm{C}$ selama $1,3,5$, dan 7 menit, kemudian diuji secara organoleptik oleh 30 orang panelis untuk menentukan suhu dan waktu perebusan terpilih.

Sampel Caulerpa sp. segar dan rebus dengan suhu dan waktu perebusan terpilih dianalisis komposisi kimianya dengan analisis proksimat menggunakan acuan AOAC (2005). Masing-masing sampel diekstrak untuk mendapatkan ekstrak kasar.

\section{Ekstraksi senyawa aktif (modifikasi Pramesti 2013)}

Metode ekstraksi yang digunakan adalah ekstraksi tunggal modifikasi Pramesti (2013) dengan menggunakan pelarut metanol dan dilakukan sebanyak 3 kali ulangan. Sampel Caulerpa sp. segar dan rebus dipotong kecil dan dihaluskan dengan mortar, kemudian ditimbang masing-masing sebanyak $100 \mathrm{~g}$, lalu dimaserasi menggunakan pelarut metanol sebanyak 200 $\mathrm{mL}$. Proses maserasi dilakukan selama $1 \times 24$ jam menggunakan orbital shaker $180 \mathrm{rpm}$. Hasil maserasi kemudian disaring dengan kertas saring sehingga diperoleh filtrat dan residu. Filtrat tersebut kemudian dievaporasi hingga pelarut terpisah dengan ekstrak menggunakan rotary vacuum evaporator pada suhu $40{ }^{\circ} \mathrm{C}$ sehingga diperoleh ekstrak kasar. Ekstrak kasar tersebut diuji aktivitas antioksidannya dengan metode DPPH.

\section{Aktivitas antioksidan metode DPPH (Salazar-Aranda et al. 2011)}

Ekstrak Caulerpa sp. segar dan rebus dari hasil ekstraksi tunggal dilarutkan dalam metanol dengan konsentrasi 100, 200, 300, 400, dan 500 $\mathrm{mg} / \mathrm{L}$. Vitamin $\mathrm{C}$ digunakan sebagai kontrol positif dan pembanding dilarutkan dalam etanol dengan konsentrasi 0,$5 ; 1 ; 2,5 ; 5 ; 7,5$; dan $10 \mathrm{mg} / \mathrm{L}$. Larutan DPPH yang digunakan dibuat dengan melarutkan kristal DPPH dalam pelarut metanol $1 \mathrm{mM}$. Larutan DPPH dipindahkan ke dalam microtiter plate sebanyak $50 \mu \mathrm{L}$ menggunakan pipet mikro, kemudian ditambahkan $150 \mu \mathrm{L}$ sampel dan $150 \mu \mathrm{L}$ kontrol standar. Campuran tersebut diinkubasi pada suhu $37^{\circ} \mathrm{C}$ selama 30 menit, kemudian diukur absorbansinya dengan menggunakan reader ELISA dengan panjang gelombang $517 \mathrm{~nm}$. 
Antioksidan dari sampel dinyatakan dengan nilai persen inhibisi. Nilai konsentrasi dan hambatan ekstrak diplot masing-masing pada sumbu $x$ dan y pada persamaan regresi linier. Persamaan garis yang diperoleh dalam bentuk $\mathrm{y}=\mathrm{b}(\mathrm{x})+\mathrm{a}$ digunakan untuk mencari nilai IC (inhibitor concentration), dengan nilai y yaitu 50 dan nilai x sebagai $\mathrm{IC}_{50}$. Nilai $\mathrm{IC}_{50}$ merupakan konsentrasi larutan sampel yang dibutuhkan untuk mereduksi 50\%DPPH.

\section{Analisis Data}

Rancangan percobaan yang dilakukan adalah uji rating hedonik dengan variasi suhu dan waktu perebusan Caulerpa sp. Uji dilakukan untuk mendapatkan suhu dan waktu perebusan terpilih yang digunakan untuk proses analisis selanjutnya. Data organoleptik yang diperoleh diolah menggunakan perangkat Microsoft Exel 2007 dan XLStat Version 2014 kemudian dilakukan uji Kruskal Wallis, apabila hasil uji Kruskal Wallis menunjukan pengaruh yang nyata, maka dilakukan uji lanjut multiple comparison (uji Dunn). Rancangan percobaan hasil analisis proksimat dan uji aktivitas antioksidan disajikan secara deskriptif dengan nilai standar deviasi untuk menentukan pengaruh perebusan yang dilakukan terhadap sampel Caulerpa sp.

\section{HASIL DAN PEMBAHASAN Morfologi Caulerpa sp.}

Sampel rumput laut Caulerpa sp. pada penelitian ini berasal dari Perairan Tual, Maluku Tenggara. Sampel ini memiliki warna hijau tua, talus berukuran $2 \mathrm{~mm}$, ramuli berbentuk bulatan-bulatan kecil yang rapat setiap percabangan sepanjang 1-5 $\mathrm{cm}$. Sampel memiliki kemiripan ciri dengan sampel Atmadja (1996) Caulerpa lentillifera, memiliki ciri-ciri talus membentuk akar berukuran $\pm 1-2$ $\mathrm{mm}$, ramuli membentuk bulatan-bulatan kecil merapat teratur menutupi setiap percabangan sepanjang $\pm 3-5 \mathrm{~cm}$, dan berwarna hijau tua. Rumput laut ini tumbuh di perairan dangkal dengan akar menancap pada substrat pasir atau menempel pada batu dengan kedalaman 1-3 meter. Sampel Caulerpa sp. dapat dilihat pada Figure 1.

\section{Organoleptik Caulerpa sp. Rebus}

Caulerpa sp. oleh masyarakat pesisir umumnya dikonsumsi sebagai urap dalam kondisi mentah maupun direbus terlebih dahulu. Suhu perebusan yang digunakan dalam penelitian ini adalah $90^{\circ} \mathrm{C}$ dan $95^{\circ} \mathrm{C}$ dengan waktu perebusan masing-masing selama 1, 3, 5, dan 7 menit. Nilai rata-rata organoleptik Caulerpa sp. rebus dilihat pada Table 1.

Caulerpa sp. rebus A905 memiliki kenampakan yang baik (agak disukai oleh penelis) dibandingkan perlakuan lainnya. Perlakuan tersebut merupakan perlakuan yang berbeda nyata dengan tujuh perlakuan lainnya. Suhu dan waktu perebusan pada perlakuan tersebut tidak merusak talus dan ramuli Caulerpa sp. sehingga masih berbentuk bulatan-bulatan kecil. Wicaksono dan Zubaidah (2015) menyatakan bahwa perebusan selama tiga sampai sepuluh menit tidak merusak talus rumput laut yang akan diolah menjadi bahan pangan.

Caulerpa sp. rebus dengan perlakuan A905 memiliki kesukaan panelis tertinggi, dan berbeda nyata dengan tujuh perlakuan lainnya. Warna Caulerpa sp. rebus dengan suhu perebusan $90{ }^{\circ} \mathrm{C}$ selama lima menit memiliki warna hijau tua yang masih agak disukai oleh panelis. Kasim (2013) menyatakan bahwa perebusan rumput laut yang dilakukan selama kurang dari sepuluh menit tidak menyebabkan perubahan warna yang nyata terhadap rumput laut tersebut.

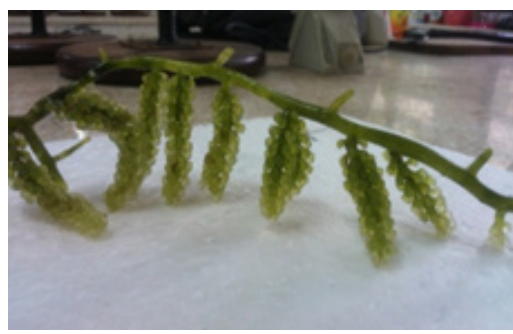

Figure 1 Caulerpa sp. from Tual Waters, Southeast Molucca 
Table 1 Organoleptic values of boiled Caulerpa sp.

\begin{tabular}{lcccccccc}
\hline \multirow{2}{*}{ Parameter } & \multicolumn{7}{c}{ Treatment (Temperature and Time) } \\
\cline { 2 - 8 } & A901 & A903 & A905 & A907 & A951 & A953 & A955 & A957 \\
\hline Appearance & $3.57^{\mathrm{a}}$ & $4.63^{\mathrm{cd}}$ & $6.23^{\mathrm{f}}$ & $4.73^{\mathrm{dc}}$ & $4.07^{\mathrm{ab}}$ & $5.47^{\mathrm{ed}}$ & $4.87^{\mathrm{d}}$ & $4.13^{\mathrm{bc}}$ \\
Color & $3.67^{\mathrm{a}}$ & $5.03^{\mathrm{cd}}$ & $6.47^{\mathrm{e}}$ & $5.53^{\mathrm{dc}}$ & $3.57^{\mathrm{ac}}$ & $5.23^{\mathrm{cd}}$ & $4.87^{\mathrm{bc}}$ & $4.47^{\mathrm{bc}}$ \\
Flavor & $3.67^{\mathrm{a}}$ & $4.97^{\mathrm{cd}}$ & $5.27^{\mathrm{d}}$ & $4.37^{\mathrm{cc}}$ & $3.93^{\mathrm{ab}}$ & $5.07^{\mathrm{cd}}$ & $4.83^{\mathrm{cc}}$ & $4.03^{\mathrm{ab}}$ \\
Taste & $3.53^{\mathrm{a}}$ & $4.23^{\mathrm{bd}}$ & $5.37^{\mathrm{d}}$ & $4.17^{\mathrm{bc}}$ & $3.93^{\mathrm{ab}}$ & $5.23^{\mathrm{dc}}$ & $4.67^{\mathrm{cc}}$ & $3.93^{\mathrm{ab}}$ \\
Texture & $3.47^{\mathrm{a}}$ & $4.93^{\mathrm{cd}}$ & $6.17^{\mathrm{d}}$ & $4.53^{\mathrm{bc}}$ & $4.53^{\mathrm{bc}}$ & $5.47^{\mathrm{dc}}$ & $4.97^{\mathrm{cc}}$ & $4.27^{\mathrm{bc}}$ \\
\hline
\end{tabular}

Note:

A901 sample Caulerpa sp. boiled at a temperature of $90^{\circ} \mathrm{C}$ for 1 minute

A903 sample Caulerpa sp. boiled at a temperature of $90^{\circ} \mathrm{C}$ for 3 minutes

A905 sample Caulerpa sp. boiled at a temperature of $90^{\circ} \mathrm{C}$ for 5 minutes

A907 sample Caulerpa sp. boiled at a temperature of $90^{\circ} \mathrm{C}$ for 7 minutes

A951 sample Caulerpa sp. boiled at a temperature of $95^{\circ} \mathrm{C}$ for 1 minute

A953 sample Caulerpa sp. boiled at a temperature of $95^{\circ} \mathrm{C}$ for 3 minutes

A955 sample Caulerpa sp. boiled at a temperature of $95^{\circ} \mathrm{C}$ for 5 minutes

A957 sample Caulerpa sp. boiled at a temperature of $95^{\circ} \mathrm{C}$ for 7 minutes

The numbers in the table followed by different letters ( $a, b, c, d, e, f)$ show significantly different $(p<0.05)$

Perlakuan A905 memiliki nilai ratarata kesukaan panelis tertinggi. Perlakuan tersebut memiliki aroma yang tidak berbeda nyata dengan perlakuan A903 dan A953, tetapi berbeda nyata dengan lima perlakuan lainnya. Caulerpa sp. rebus dengan perlakuan A905 memiliki bau spesifik rumput laut dengan aroma sedikit amis. Perlakuan A905 memiliki nilai rata-rata kesukaan panelis tertinggi. Perlakuan tersebut memiliki rasa yang tidak berbeda nyata dengan perlakuan A953, namun berbeda nyata dengan enam perlakuan lainnya. Caulerpa sp. rebus dengan perlakuan tersebut memiliki rasa asin serupa air laut. Perlakuan A905 memiliki nilai ratarata kesukaan panelis tertinggi. Perlakuan tersebut memiliki tekstur yang tidak berbeda nyata dengan perlakuan A953, tetapi berbeda nyata dengan enam perlakuan lainnya. Caulerpa sp. rebus dengan perlakuan A905 memiliki tekstur yang kenyal dan tidak lembek yang masih agak disukai oleh panelis. Suter et al. (2011) menyatakan perebusan yang dilakukan selama lima menit tidak mengakibatkan perubahan pada tekstur rumput laut rebus.

Caulerpa sp. rebus dengan perlakuan A905 pada parameter kenampakan dan warna berbeda nyata dengan tujuh perlakuan lainnya, namun pada parameter aroma tidak berbeda nyata dengan perlakuan A903 dan A953, parameter rasa dan tekstur tidak berbeda nyata dengan perlakuan A953. Perlakuan A905 memiliki nilai rata-rata uji organoleptik tertinggi dibandingkan perlakuan lainnya, dan merupakan perlakuan yang agak disukai oleh panelis sehingga dijadikan sebagai suhu dan waktu terpilih untuk menganalisis Caulerpa sp. rebus.

\section{Komposisi Kimia Caulerpa sp. Segar dan Rebus}

Hasil analisis proksimat Caulerpa sp. segar dan rebus (basis basah) dapat dilihat pada Table 2, dan hasil perhitungan analisis proksimat Caulerpa sp. segar dan rebus.

Caulerpa sp. segar memiliki kadar air yang cukup tinggi yaitu $76,47 \pm 0,09 \%$ dan menjadi $79,43 \pm 0,19 \%$ setelah dilakukan perebusan. Hasil tersebut lebih rendah jika dibandingkan penelitian Nguyen et al. (2011) dengan komposisi kadar air C. lentillifera yang berasal dari perairan Taiwan yaitu 94,28 $\pm 0,24 \%$ (basis basah), dan kadar air basis basah C. racemosa dari perairan Jepara yaitu 92,37\% (Ma'ruf et al. 2013). Perbedaan persentase kadar air yang dihasilkan dapat disebabkan karena adanya proses transportasi melalui udara dan daratpada sampel. Mảruf et al. (2013) menyatakan bahwa transportasi dapat menyebabkan pecahnya ramuli-ramuli Caulerpa sp. yang berisi air dan dapat memicu proses respirasi dan transpirasi sehingga mempercepat penguapan air pada 
Table 2 Proximate composition of fresh and boiled Caulerpa sp.

\begin{tabular}{lrr}
\hline \multicolumn{1}{c}{ Chemical Composition (\%) } & Fresh Caulerpa sp. & Boiled Caulerpa sp. \\
\hline Moisture & $76.47 \pm 0.09$ & $79.43 \pm 0.19$ \\
Ash & $1.33 \pm 0.12$ & $1.03 \pm 0.06$ \\
Protein & $3.58 \pm 0.14$ & $3.37 \pm 0.1$ \\
Fat & $0.35 \pm 0.04$ & $0.4 \pm 0.03$ \\
Carbohydrate (by difference) & $18.27 \pm 0.08$ & $15.76 \pm 0.19$ \\
\hline
\end{tabular}

sampel yang menyebabkan rendahnya kadar air Caulerpa sp. Perubahan persentase kadar air Caulerpa sp. rebus dapat disebabkan karena terserapnya air perebusan oleh matrik jaringan. Pernyataan ini diperkuat oleh pernyataan Aisyah et al. (2014) bahwa perebusan dan pengukusan dapat menyebabkan matrik jaringan sayuran cenderung menyerap air sehingga kandungan airnya relatif lebih tinggi daripada sayuran segar.

Hasil penelitian menunjukkan Caulerpa sp. segar memiliki persentase kadar abu yaitu $1,33 \pm 0,12 \%$ dan $1,03 \pm 0,06 \%$ setelah proses perebusan. Hasil tersebut didukung oleh penelitian Nguyen et al. (2011) dengan kadar abu basis basah yaitu $1,27 \pm 0,02 \%$. Proses perebusan yang dilakukan menyebabkan perubahan persentase kadar abu sampel Caulerpa sp. yaitu 0,3\%. Sipayung et al. (2015) menyatakan komponen abu suatu bahan mudah mengalami dekomposisi atau bahkan menguap pada suhu yang tinggi, sehingga proses perebusan yang dilakukan dapat menurunkan persentase kadar abu yang dihasilkan. Purwaningsih (2012) menjelaskan bahwa kadar abu merupakan campuran dari komponen anorganik atau mineral yang terdapat dalam bahan pangan. Kadar abu dapat dijadikan sebagai petunjuk akan keberadaan mineral suatu bahan. Bahan makanan sendiri terdiri atas $96 \%$ zat organik dan air, sedangkan sisanya terdiri atas unsur mineral atau zat anorganik (Winarno 2008).

Kadar protein Caulerpa sp. segar yaitu $3,58 \pm 0,14 \%$ dan $3,37 \pm 0,1 \%$ setelah proses perebusan. Proses perebusan ini tidak menyebabkan perubahan kadar protein Caulerpa sp. karena perebusan yang dilakukan hanya lima menit. Susilawati (2007) menyatakan bahwa perubahan kadar protein suatu bahan pangan yang dipanaskan dipengaruhi oleh lama pemanasan bahan pangan tersebut. Bahan pangan yang diolah dengan menggunakan panas dalam waktu lebih dari 15 menit dapat menyebabkan perubahan kadar protein dan lemaknya. Kadar protein Caulerpa sp. segar yang dihasilkan lebih rendah jika dibandingkan penelitian Kumar et al. (2011) dengan kadar protein C. racemosa basis basah yaitu $7,77 \pm 0,59 \%$. Ratana dan Chirapart (2006) menyatakan bahwa kandungan protein yang berbeda dalam rumput laut disebabkan oleh perbedaan spesies, musim, dan kondisi geografis, serta kandungan asam amino didalamnya. Megayana et al. (2012) menyatakan bahwa kondisi nutrisi yang terkandung di habitat memberikan pengaruh terhadap komposisi kimia pada organisme yang hidup di wilayah tersebut.

Caulerpa sp. segar mengandung kadar lemak yang rendah, yaitu $0,35 \pm 0,04 \%$ dan $0,4 \pm 0,03 \%$ setelah proses perebusan. Proses perebusan yang dilakukan tidak menyebabkan perubahan persentase kadar lemak Caulerpa sp. karena perebusan hanya dilakukan selama lima menit. Indriastuti et al. (2012) menyatakan bahwa komposisi kimia suatu bahan pangan yang diproses dengan metode pemanasan dan pemasakan pada suhu tertentu akan menyebabkan perubahan kandungan protein dan lemak, namun tetap pada komposisi kimia yang proporsional yaitu nilai kandungan lemak lebih tinggi akan direfleksikan dengan kandungan protein yang lebih rendah begitu pula sebaliknya. Persentase kadar lemak Caulerpa sp. segar tidak berbeda dengan hasil penelitian Matanjun et al. (2009) yaitu C. lentillifera dari perairan Semporna, Malaysia yaitu $1,01 \pm 0,05 \%$ (basis basah). Kadar lemak yang rendah dapat disebabkan oleh kandungan kadar air yang cukup tinggi 
sehingga kadar lemak secara proporsional menurun. Kadar air umumnya berbanding terbalik dengan kadar lemak. Hubungan tersebut mengakibatkan semakin rendahnya kadar lemak jika kadar air yang terkandung dalam bahan memiliki jumlah yang tinggi (Yunizal et al. 1998).

Kadar karbohidrat (by difference) Caulerpa sp. segar yaitu $18,27 \pm 0,08 \%$ dan mengalami penurunan menjadi $15,76 \pm 0,19 \%$ setelah proses perebusan. Hasil perhitungan karbohidrat dengan metode by difference ini merupakan metode penentuan kadar karbohidrat dalam bahan secara kasar, serat kasar juga dihitung sebagai karbohidrat (Winarno 2008). Hasil karbohidrat tersebut lebih rendah dibandingkan dengan hasil penelitian Matanjun et al. (2009), yaitu $38,66 \pm 0,96 \%$ (basis basah). Karbohidrat merupakan sumber energi utama bagi hampir seluruh penduduk dunia dan sumber kalori yang murah dibandingkan dengan protein dan lemak, serta berperan dalam metabolisme tumbuhan dan hewan (Winarno 2008).

\section{Aktivitas Antioksidan Caulerpa sp.}

Hasil ekstraksi tunggal dengan pelarut metanol berbentuk pasta dengan sedikit cairan. Caulerpa sp. segar memiliki rendemen yaitu $8,88 \%$ dan Caulerpa sp. rebus memiliki rendemen yaitu 6,44\%. Nugroho (2012) menyatakan bahwa perbedaan rendemen ekstrak sampel segar dan sampel rebus disebabkan karena hilangnya senyawasenyawa aktif pada saat proses perebusan. Tingginya rendemen yang dihasilkan diduga karena masih adanya air dalam hasil ekstrasi tunggal. Hasil rendemen tersebut lebih tinggi dibandingkan dengan penelitian Maulida (2007) bahwa C. lentillifera segar dari Teluk Betung, Lampung yang diekstrak dengan pelarut metanol memiliki rendemen yaitu 3,06\%. Perbedaan hasil tersebut dapat disebabkan karena peredaan metode ekstraksi yang digunakan, yaitu ekstraksi bertingkat dengan pelarut n-heksana, etil asetat, dan metanol. Kumar et al. (2012) menyatakan, rendemen ekstrak yang dihasilkan suatu bahan dipengaruhi oleh metode ekstraksi yang digunakan, pelarut, dan umur panen. Selain perbedaan metode ekstraksi, perbedaan habitat sampel Caulerpa sp. yang digunakan juga mempengaruhi kandungan senyawa aktif dari suatu bahan.

Mekanisme penangkapan radikal DPPH, yaitu melalui donor atom $\mathrm{H}$ dari senyawa antioksidan yang menyebabkan peredaman warna radikal pikrilhidrazil yang berwarna ungu menjadi pikrilhidrazil berwarna kuning yang nonradikal (Molyneux 2004).

Vitamin C atau asam askorbat merupakan senyawa antioksidan alami yang digunakan sebagai kontrol positif dan pembanding. Hasil pengujian aktivitas antioksidan pada ekstrak Caulerpa sp. (segar dan rebus) dan vitamin C disajikan pada Table 3.

Aktivitas antioksidan menunjukkan Caulerpa sp. segar memiliki nilai $\mathrm{IC}_{50}$ yaitu $452,37 \pm 8,29 \mathrm{mg} / \mathrm{L}$ dan setelah proses perebusan menjadi 484,59 $\pm 5,69 \mathrm{mg} / \mathrm{L}$. Proses perebusan yang dilakukan mengakibatkan menurunnya aktivitas antioksidan dari Caulerpa sp. tersebut. Penurunan aktivitas antioksidan Caulerpa sp. rebus dapat terlihat dengan adanya kenaikan nilai $\mathrm{IC}_{50}$ setelah proses perebusan yaitu $32,22 \mathrm{mg} / \mathrm{L}$. Penurunan aktivitas antioksidan ini diakibatkan karena adanya proses pemanasan dengan suhu 90 ${ }^{\circ} \mathrm{C}$. Farasat et al. (2014) menjelaskan bahwa proses pemanasan dapat menyebabkan hilangnya sebagian senyawa bioaktif dan kerusakan struktur senyawa yang berfungsi sebagai antioksidan, sehingga menyebabkan bahan tersebut kehilangan kemampuannya

Table 3 Antioxidant activity of extracts of Caulerpa sp. and vitamin C

\begin{tabular}{lr}
\hline \multicolumn{1}{c}{ Extract } & IC $_{50}$ value $(\mathrm{ppm})$ \\
\hline Fresh Caulerpa sp. & $452.37 \pm 8.29$ \\
Boiled Caulerpa sp. & $484.59 \pm 5.69$ \\
Vitamin C $^{(\mathrm{a})}$ & $3.71 \pm 0.27$ \\
Caulerpa lentillifera $^{(\mathrm{b})}$ & 356.12 \\
\hline Note: (a) positive control; (b) Maulida (2007)
\end{tabular}


sebagai antioksidan. Oboh (2005) menyatakan penurunan vitamin C sebesar 32-68\% kehilangan vitamin $\mathrm{C}$ selama penanganan dan pengolahan beberapa sayuran tropis. Salah satu vitamin yang berperan sebagai antioksidan yang terdapat dalam tumbuhan adalah asam.

Nilai $\mathrm{IC}_{50}$ Caulerpa sp. segar dan rebus masing-masing yaitu $452,37 \pm 8,29 \mathrm{mg} / \mathrm{L}$ dan $484,59 \pm 5,69 \mathrm{mg} / \mathrm{L}$, berdasarkan nilai tersebut aktivitas antioksidan Caulerpa sp. segar dan rebus termasuk ke dalam kategori antioksidan sangat lemah karena memiliki nilai $\mathrm{IC}_{50}$ lebih dari $200 \mathrm{mg} / \mathrm{L}$. Vitamin C sebagai kontrol positif dan standar yang digunakan termasuk antioksidan dengan kategori sangat kuat karena memiliki nilai IC $_{50}$ kurang dari 50 $\mathrm{mg} / \mathrm{L}$, yaitu 3,71 mg/L. Aktivitas antioksidan Caulerpa sp. segar yang dihasilkan lebih kuat bila dibandingkan dengan penelitian Nurjanah et al. (2012) yang menyatakan bahwa $\mathrm{IC}_{50}$ pada semanggi air segar yaitu 634,73 mg/L, dan penelitian Aryudhani (2007) yang menyatakan bahwa $\mathrm{IC}_{50}$ pada C. racemosa segar yaitu $41625,76 \mathrm{mg} / \mathrm{L}$. Aktivitas antioksidan Caulerpa sp. rebus yang dihasilkan lebih kuat bila dibandingkan dengan penelitian Nurjanah et al. (2014) yang menyatakan bahwa $\mathrm{IC}_{50}$ genjer rebus selama tiga menit dan lima menit masingmasing yaitu $1350 \mathrm{mg} / \mathrm{L}$ dan $3409 \mathrm{mg} / \mathrm{L}$. Chew et al. (2011) menyatakan bahwa nilai $\mathrm{IC}_{50}$ suatu bahan alami berhubungan erat dengan senyawa bioaktif yang dikandungnya dan pemilihan metode ekstraksi yang digunakan.

\section{KESIMPULAN}

Antioksidan ekstrak kasar Caulerpa sp. segar dan rebus tergolong sangat lemah berdasarkan metode pengujian DPPH. Perebusan pada suhu $90{ }^{\circ} \mathrm{C}$ selama lima menit menyebabkan turunnya aktivitas antioksidan Caulerpa sp. Caulerpa sp. dapat dikonsumsi sebagai makanan tambahan yang mengandung aktivitas antioksidan, dan dapat dijadikan sebagai salah satu bahan baku alternatif antioksidan alami.

\section{DAFTAR PUSTAKA}

Aisyah Y, Rasdiansyah, Muhaimin. 2014. Pengaruh pemanasan terhadap aktivitas antioksidan pada beberapa jenis sayuran. Jurnal Teknologi dan Industri Pertanian Indonesia. 6(2): 1-6.

[AOAC] Association of Official Analitycal Chemist. 2005. Official Method of Analysis of The Association of Official Analytical of Chemist. Virginia (US): Association of Official Analytical Chemist, Inc.

Aryudhani N. 2007. Kandungan senyawa fenol rumput laut Caulerpa racemosa dan aktivitas antioksidannya. [skripsi]. Bogor (ID): Fakultas Perikanan dan Ilmu Kelautan, Institut Pertanian Bogor.

Atmadja WS, Kadi A, Sulistijo, Rachmaniar. 1996. Pengenalan Jenis-Jenis Rumput Laut Indonesia. Jakarta (ID): Puslitbang Oseanologi-LIPI.

[BSN]. Badan Standardisasi Nasional. 1995. SNI 01-0222-95 Bahan Tambahan Makanan. Jakarta (ID): Badan Standardisasi Nasional.

Chew KK, Ng SY, Thoo YY, Khoo MZ, Wan Aida WM, Ho CW. 2011. Effect of ethanol concentration, extraction time and extraction temperature on the recovery of phenolic compounds andantioxidant capacity of Centella asiatica extracts. International Food Research Journal. 18: 566-573.

Deepa N, Kaur C, George B, Singh B, Kapoor HC. 2007. Antioxidant constituents in some sweet pepper (Capsicum annuum L.) genotypes during maturity. LWT-Food Science and Technology. 40(1): 121-129.

Farasat M, Khavari-Nejad RA, Nabavi SMB, Namjooyan F. 2014. Antioxidant activity, total phenolics and flavonoid contents of some edible green seaweeds from northern coasts of the persian gulf. Iranian Journal of Pharmaceutical Research. 13(1): 163-170.

Indriastuti ATD, Setiyono, Erwanto Y. 2012. Pengaruh jus daun sirih sebagai bahan pracuring dan lama penyimpanan terhadap komposisi kimia dan angka peroksida dendeng ayam petelur. Agrinimal. 2(1): 1-5. 
Jebakumar AZ, Hassan SN, Siju KG, Manoj G. 2012. Natural anti-oxidants and invitro methods for anti-oxidant activity. International Journal of Pharmacology Research .2(1): 46-55.

Kasim S. 2013. Pengaruh konsentrasi natrium hidroksida terhadap rendemen karaginan yang diperoleh dari rumput laut jenis Eucheuma spinosum asal kota bau-bau. Jurnal Farmasi dan Farmakologi. 17(1): 1-8.

Kumar A, Kumari SN, Bhargavan D. 2012. Evaluation of in vitro antioxidant potential of ethanolic extract from the leaves of Achyranthes aspera. Asian Journal of Pharmaceutical and Clinical Research. 5(3): 146-148

Kumar M, Vishal G, Puja K, Reddy CRK, Jha B. 2011. Assessment of nutrient composition and antioxidant potential of Caulerpaceae seaweeds. Journal of Food Composition and Analysis. 24(1): 270-278.

Ma’ruf WF, Ratna I, Eko ND, Eko S, Ulfah A. 2013. Profil rumput laut Caulerpa racemosa dan Gracilaria verrucosa sebagai edible food. Jurnal Saintek Perikanan. 9(1): 68-74.

Matanjun P, Mohamed S, Mustapha NM, Muhammad K. 2009. Nutrient content of tropical edible seaweeds, Eucheuma cottonii, Caulerpa lentillifera, and Sargassum polycystum. Journal of Applied Phycology. 21(1): 75-80.

Maulida R. 2007. Aktivitas antioksidan rumput laut Caulerpa lentillifera. [skripsi]. Bogor (ID): Fakultas Perikanan dan Ilmu Kelautan, Institut Pertanian Bogor.

Megayana Y, Subekti S, Alamsjah MA. 2012. Studi kandungan alginate dan klorofil rumput laut Sargassum sp. pada umur panen yang berbeda. Journal of Aquaculture and Fish Health. 1(1): 120127.

Molyneux P. 2004. The use of the stable free radical diphenylpicryl-hydrazyl (DPPH) for estimating antioxidant activity. Journal Science of Technology. 26(2): 211-219.

Nguyen VT. Ueng J, Tsai G. 2011. Proximate composition, total phenolic content, and antioxidant activity of seagrape (Caulerpa lentillifera). Journal of Food Science. 76(7): 950-958.

Nufus C, Nurjanah, Abdullah A. 2017. Karakteristik rumput laut hijau dari perairan Kepulauan Seribu dan Sekotong Nusa Tenggara Barat sebagai antioksidan. Jurnal Pengolahan Hasil Perikanan Indonesia. 20(3): 620-632.

Nugroho M. 2012. Pengaruh suhu dan lama ekstraksi secara pengukusan terhadap rendemen dan kadar albumin ikan gabus (Ophiocephalus striatus). Jurnal Teknologi Pangan. 3(1): 64-75.

Nurjanah, Nurimala M, Hidayat T, Sudirjo F. 2016. Characteristics of seaweed as raw materials for cosmetics. Aquatic Procedia. 7:177-180.

Nurjanah, Jacoeb AM, Asmara DA, Hidayat T. Phenolic compound of fresh and boiled sea grapes (Caulerpa sp.) From Tual, Maluku. Food Science Technology Journal. 1(1):31-39

Nurjanah, Jacoeb AM. Hidayat T. Chrystiawan R. 2018. Perubahan komponen serat rumput laut Caulerpa sp (dari Tual Maluku) akibat proses perebusan. Jurnal Ilmu Teknologi Kelautan Tropis. 10 (1): 35-48.

Nurjanah, Azka A, Abdullah A. 2012. Aktivitas antioksidan dan komponen bioaktif semanggi air (Marsilea crenata). Jurnal Inovasi dan Kewirausahaan. 1(3): 152-158.

Nurjanah, Jacoeb AM, Hidayat T, Shylina A. 2015. Bioactive compounds and antioxidant activity of lindur stem bark (Bruguiera gymnorrhiza). International Journal of Plant Science and Ecology. 1(5):182-189.

Nurjanah, Jacoeb AM, Nugraha R, Permatasari M, Sejati TKA. 2014. Perubahan komposisi kimia, aktivitas antioksidan, vitamin $\mathrm{c}$ dan mineral tanaman genjer (Limnocharis flava) akibat pengukusan. Jurnal Inovasi dan Kewirausahaan. 3(3): 185-195.

Oboh G. 2006. Antioxidant and antimicrobial properties of ethanolic extract of Ocimum gratissium leaves. Journal of Pharmacology and Toxicology. 1(1): 47-53. 
Pramesti R. 2013. Aktivias antioksidan ekstrak rumput laut Caulerpa serrulata dengan metode DPPH (1,1 definil 2 pikrilhidrazil). Buletin Oseanografi Marina. 2(2): 7-15.

Purwaningsih S. 2012. Aktivitas antioksidan dan komposisi kimia keong matah merah (Cerithidea obtusa). Jurnal Ilmu Kelautan. 17(1):39-48.

Ratana P, Chirapart A. 2006. Nutritional evaluation of tropical green seaweeds Caulerpa lentillifera and Ulva reticulata. Kasetsart Journal (National Science). 40(1): 75-83.

Salazar-Aranda R, Perez-Lopes LA, LopezArroyo J, Alanis-Garza BA, Waksman de Torres N. 2011. Antimicrobial and antioxidant activities of plants from Northeast of Mexico. Evidence-Based Complementary and Altenative Medicine. 1(1): 1-6.

Santoso J, Anwariyah S, Rumiantin RO, Putri AP, Ukhty N, Yoshie Y. Phenol content, antioxidant activity and fibers profile of four tropical seagrasses from Indonesia. Journal of Coastal Development. 15(2): 189-196.

Setyaningsih D, Apriyantono A, Sari MP. 2010. Analisis Sensori untuk Industri Pangan dan Agro. Bogor (ID): IPB Press.

Sipayung MY, Suparmi, Dahlia. 2015. Pengaruh suhu pengukusan terhadap sifat fisika kimia tepung ikan rucah. Jurnal Pengolahan Unri. 2(1): 1-13.

Sudirman S, Nurjanah, Jacoeb AM. 2014. Proximate compositions, bioactive compounds and antioxidant activity from large-leafed mangrove (Bruguiera gymnorrhiza) fruit. International Food Research Journal. 21(6): 2387-2391.

Sultana V, Baloch GN, Ambreen AJ, Tariq MR, Ehteshamul-Haque S. 2011. Comparative efficacy of a red alga Solieria robusta, chemical fertilizers and ZZ pesticides in managing the root diseases and growth of soybean. Pakistan Journal of Botany. 43(1): 1-6.

Susilawati I. 2007. Kajian metode pengasapan dalam pengolahan dendeng batokok produk khas sumatera barat. [tesis]. Bogor (ID): Sekolah Pascasarjana Teknologi Pasca Panen, Institut Pertanian Bogor.

Suter IK, Wijaya IMAS, Yusa NM. 2011. Formulasi ledok instan yang ditambahkan ikan tongkol dan rumput laut. Jurnal Teknologi dan Industri Pangan. 22(2): 190-196.

Tamat SR, Wikanta T, Maulina LS. 2007. Aktivitas antioksidan dan toksisitas senyawa bioaktif dari ekstrak rumput laut hijau Ulva reticulata Forsskal. Jurnal Ilmu Kefarmasian Indonesia. 5(1): 31-36.

Udayaprakash NK, Ranjithkumar M, Deepa S, Sripriya N, Al-Arfaj AA, Bhuvaneswari S. 2015. Antioxidant, free radical scavenging and GC-MS composition of Cinnamomum iners. Industrial Crops and Products. 69(3): 175-178.

Usmiati S, Nurdjannah N. 2007. Pengaruh lama perendaman dan cara pengeringan terhadap mutu lada putih. Jurnal Pertanian Indonesia. 16(3): 91-98.

Wicaksono GS, Zubaidah E. 2015. Pengaruh karagenan dan lama perebusan daun sirsak terhadap mutu dan karakteristik jelly drink daun sirsak. Jurnal Pangan dan Agroindustri. 3(1): 281-291.

Winarno FG. 2008. Kimia Pangan dan Gizi. Bogor (ID): M-Brio Press.

Yunizal, Murtini JT, Dolaria N, Purdiwoto B, Abdulrokhim, Carkipan. 1998. Prosedur Analisis Kimiawi Ikan dan Produk Olahan Hasil-Hasil Perikanan. Jakarta (ID): Pusat Penelitian dan Pengembangan Perikanan. 